ELORE (ISSN 1456-3010), vol. 15 - 1/2008.

Julkaisija: Suomen Kansantietouden Tutkijain Seura ry.

[http://www.elore.fi/arkisto/1_08/kam1_08.pdf]

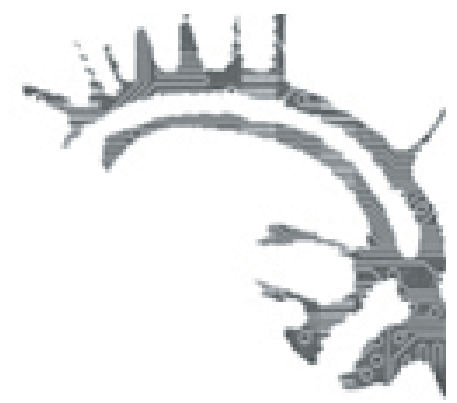

\title{
Becoming a "Practising" Muslim - Reflections on Gender, Racism and Religious Identity among Women in a Swedish Muslim Youth Organisation
}

\author{
$\underline{\text { Pia Karlsson Minganti }}$
}

In today's Sweden there live an estimated 300000 Muslims. Some perceive themselves as religious, some do not. As an ethnologist, since the mid-1990s I have been specializing on Muslims' lives in Sweden, with a specific focus on those considering themselves as being devout believers. Initially, I examined the processes of establishing mosques; more specifically, I problematized the relations between the minority and majority, freedom of religion, politics of heritage, and the contestation of public space (Karlsson Minganti 2004; Karlsson \& Svanberg 1995; 1997). In my doctoral thesis I highlighted the global Islamic revival and the creation of an "Islamic" identity in a Swedish context. It was above all the Sunni-dominated national organization Sveriges Unga Muslimer (SUM, i.e., Sweden's Young Muslims) that was focussed on. The aim was to analyse women members' negotiations on gender, taking into consideration both the hindering and the empowering effects on their agency (Karlsson Minganti 2007).

In this article I will draw on the findings from my thesis for the analysis of young devout women - or "practising" Muslims, as they preferred to define themselves. The aim is to illuminate the women's construction of an "Islamic" identity, and further, its possibly beneficial implications for their agency, primarily in association with racist and sexist oppression. I will do so by highlighting a key scenario in the women's narratives about their development as Muslims, containing the following three aspects: 1) being born into a Muslim family with Islam as the tacit "common sense"; 2) going through a teenage crisis when meeting with the world outside the home sphere, including racism and critical reflections on sexism; 3) being religiously awakened when enrolling in Muslim youth associations, and consequently, in the global Islamic revival. I will claim that this key scenario reflects points of conflict for 


\section{Becoming a "Practising" Muslim}

the women, in the intersection between gender, religion, "race"/ethnicity and generation. I will also claim that such scenario indicates a distinction between "religion" and "cultural traditions", which is commonly used among adherents of the contemporary Islamic revival all over the world - a distinction which allows for some reinterpretation and change. Thus a crucial ambition with this article is to show how the position of an awakened, "practising" Muslim carries with it promises of empowerment for the women, making it more understandable why they would choose to engage in a seemingly gender-conservative religious movement.

\section{Theoretical, Methodological, and Ethical Considerations}

I carried out an extensive fieldwork among "practising" Muslim women engaged in the SUM and its local youth associations between 1998 and 2002. The method used was qualitative with repeated interviews and observations, resulting in printed transcriptions and fieldnotes. Each woman was interviewed two to five times, from one to two hours. They were invited to stop the interview as well as their participation in the study at any time. They were also asked if they accepted the interviews to be recorded, which, in fact, they all did. I asked them to choose a suitable place to meet, and we usually ended up at cafés, in rooms in their schools or local youth associations (at times when activities were not ongoing), or in their homes (apart from the family members, except when they wanted to speak to the women or offered us something to eat or drink). The young women invited me to follow them in different situations for observations and spontaneous conversations. These situations could be encapsulated into three main domains: 1) homes; 2) mosques and associations (during prayers and preaching, festivities and everyday life, at courses, conferences, camps, and coffee breaks); 3) public spaces where they spent their leisure time (cafés, cinemas, shops, and street). Two more domains were touched upon in interviews and talks, namely the women's school and workplace environments.

When I first met the women, they were between 18 and 25 years old, still unmarried. Some were upper secondary students, others had begun higher education or employment. They were all born in countries of West Asia, North and East Africa, to parents who, one way or another, defined themselves as Muslims, and they had all come to Sweden during childhood (at four to eleven years of age). Herein I have made the women anonymous to an extent that is worth commenting on. In order to make them recognizable neither to their family members, nor among themselves, I have chosen not to reveal any further details about their ethnic or social backgrounds or their local youth associations. This means that my analysis does not take into consideration particular ethnicities, but "ethnicity" as a relevant category for the women themselves and as an analytical tool for me as a researcher. Above all, it is the women's construction of a common religious (Islamic) identity that is focused upon. 


\section{Pia Karlsson Minganti}

The theoretical point of departure is that of the subject as a seat of intersecting identifications and power orders, resulting in different experiences and interests, sometimes coherent and sometimes in conflict. This theoretical perspective is called intersectionality and it includes different categories that position and hierarchize people - in this article primarily by gender, "race"/ ethnicity and religion (Anthias \& Yuval-Davis 1992; De los Reyes \& Gröndahl 2007; Karlsson Minganti 2007). The basic premise of intersectionality is that identities and power orders are socially and culturally constructed. To underscore this power perspective, I have chosen to work with the concept of negotiation, that is, processes that lead to social or cultural reproduction or change. People struggle to make their actions (verbal and non-verbal) appear meaningful - this is a struggle for the precedence of interpretation (Khan 2002; Thurén 1998). Also religion is, in this context, understood as contested knowledge, providing people with frames of reference and means to deal with everyday life (Berger \& Luckmann 1991; Mahmood 2005).

My ethical considerations (in addition to the anonymization of the women discussed above) draw on the reflexivity debate in anthropology and ethnology (Clifford \& Marcus 1986; Mascia-Lees \& Johnson Black 2000). Especially important is the postcolonial criticism of how researchers' constructions of the Other contribute to the maintenance of unequal structures. Edward Said has shown how academic "Orientalism" has legitimized colonial oppression and exploitation (Said 1978), and researchers like Chandra Mohanty have emphasized how generalizing descriptions of "the third-world-woman" contribute to "keeping them in place" (Mohanty 2003). Thus, a basic question is: Who am I with my specific situated knowledge (Haraway 1991, 11), as a "white" "non-Muslim" academician, to represent the voices of the young women in my study?

With regard to the complexity of this dilemma (see Karlsson Minganti 2007, 28-50), my objective is to highlight the women's agency and empowerment at the same time as I allow myself to scrutinize the possible hindrances (stemming from both the majorities and minorities). I am doing so, being influenced by the postcolonial critique of the racialized oppression of the Other, but also by a feminist perspective that calls to attention the oppression of women as the minorities' "internal Others" (Anthias \& Yuval-Davis 1992; Okin 1999). Here I would also like to emphasize that my understanding of agency goes beyond the "traditional", secular-liberal feminist perspective, reducing it to a matter of individual autonomy. I rather join Saba Mahmood's criticisms, which point at the possibility for women (and men) to experience agency when submitting to pious self-formation in accordance with "passive" virtues, such as obedience, patience and chastity (Mahmood 2005, 15, 120).

Last but not least, I would like to emphasize the dilemma of the studying processes of identification and subordination. As Floya Anthias has pointed out, these are hardly issues that are expressed explicitly by the studied subjects, but rather illuminated by the researcher's analyses of their narratives on their lives, experiences, and self-apprehensions (Anthias 2002). Further, research should not be limited to the thematic description of the studied persons' understandings, but should also include an analysis from the researcher's perspective, with a clear distinction between the two. 


\section{Becoming a "Practising" Muslim}

As for the disposition of the article, the two opening chapters coincide with the first two aspects of the key scenario mentioned above, that is, "being born a Muslim" and "going through a teenage crisis". They are followed by a chapter which aims at deepening the understanding of the crisis in terms of the women's reflections on racist and sexist oppression. In the next three chapters I delve into the third and last aspect of the key scenario, namely "becoming a 'practising' Muslim". I illuminate the women's enrolment in Muslim youth associations, the creation of their pious selves, as well as the common Islamic identity. Finally, with these pious subjects of a "new Muslim generation", I discuss the women's apprehension of Islam as a way out of racist and sexist oppression.

\section{Born A Muslim}

All human beings are born Muslims. This was the widest definition of "Muslimness" presented to me by the young women. Later, the child's piety depends on the parents' character and nurture. The children born into Muslim families, as was the case with all of the nine women within my study, are considered lucky. By mere upbringing they are made aware of God's all-encompassing presence and the basic five pillars of Islam. In fact, regardless of the women's families' diverse social and ethnic backgrounds as well as the degree of religiosity, they all transmitted to their daughters a firm belief in God. According to the women, this religious transmission occurred trough observing, imitating and listening to people in their immediate environment. With Peter L. Berger and Thomas Luckmann's sociology of knowledge in mind, I could say that the women went through a primary socialisation with their significant others, i.e., family members for the most part, as models (Berger \& Luckmann 1991, 149-151). Referring to Pierre Bourdieu, one could say that they attained an unspoken common sense, doxa, embodied in their individual babitus (Bourdieu 1977).

The women within my study were all born in countries of West Asia and North and East Africa, and they had come to Sweden during childhood, at four to eleven years of age. They grew up with different ethnic and social backgrounds, and thus with a variety of interpretations and ways of practising Islam. Also the degree of religiosity varied in the women's families. While some parents would regularly attend the mosque, others did not even pray at home. Some of the women were put into the so-called Koran schools, which means that they were acquainted with the Koran, classic Arabic, Islamic storytelling, and manners for a couple of hours every week. Several of them, however, grew up without regular contact with religious institutions, due to lack of them in their Swedish neighbourhoods or their parents' indifference.

By meeting with peers in their Muslim youth associations, they strived to overcome such internal diversity and what they perceived as parental shortcomings in religious education. As awakened Muslims they were grateful to their parents for giving them the basic ground for Islamic faith. At the same time they came to see childrearing as a process permeated by culturally grounded human "misconceptions" 


\section{Pia Karlsson Minganti}

of "true" Islam. Their Islamic groups provided them with tools for reflexive and critical thinking about their upbringing, which turned out to be urgently important to them during their teens.

\section{CRisis ANd Discontinuity}

While religious transmission to daughters embodied the elders' hopes for continuity, at times the situation turned out to be quite the reverse. All the women's narratives contain descriptions of teenage crises that threatened their bonds to both the family and religion. Besides all the possible conflicts that young people might endure, these women's narratives explicitly tell about problematic relations in association with gender and "race"/ethnicity. As the first example, I quote (in translation from Swedish into English) a woman whom I call Noor:

I would like to work as a psychologist. To help the young ones here. I feel that they need so much help, and I have been young myself. I know how it is. Really. One is so mixed up. It's really unbelievable. Sometimes I'm so happy, like: "Oh, my God, thank you for letting me survive!" Who knows where I could have ended up? I planned so much. I would run away from home, I would do this and that, become a guerrilla fighter [in her former home country, author's comment]. But here I am today.

Pia: What was so difficult?

Noor: This thing with the family. This thing with the identity. And school. It is chaos up here [touches her head]. One does not know who one is, or where one should turn oneself. I mean, I already had a hard time getting into that... what should I say, Swedishness. And then I discovered that: "Nope, I cannot become Swedish, either". Or rather, I am not allowed to do it. Just when the family noticed that: "Okay, that's it, now she is becoming Swedish... then they put up even more severe demands and boundaries. (Interview / Karlsson Minganti.)

I got the impression that Noor understood her "crisis" as self-evident to a degree that she did not need to specify any further. I interpret this as an expression of her expectations for an intertextual understanding between the two of us, that is, mutual knowledge about contemporary discourses on "this-thing-with" cultural clashes, identity crises among the immigrant youth, and oppression of immigrant girls in patriarchal contexts. During our talks, however, she specified the demands and boundaries drawn by her family members, mainly in connection to descriptions of her experiences of wearing a bijab, that is, a headscarf commonly used by contemporary Muslim women worldwide, and a powerful key symbol loaded with messages about essential beliefs and values (Ortner 1973, 1339).

Noor: I was supposed to wear a headscarf. My family forced me. It has always been important to my father that we maintain our roots. But I took. it off. I wore it when 


\title{
Becoming a "Practising" Muslim
}

\begin{abstract}
I left home and then I sneaked into some stairway and took it off before arriving at school. That was a really hard time. I guess one could call that a crisis, when I didn't know what to do. On the one hand, it worried me that the family might see me in town or somewhere without the headscarf. And then I didn't want my schoolmates to see me with the headscarf. This was the kind of anxiety that I would feel all the time during that period.

$[\ldots]$

It's not easy to be young. And especially not a young woman. I mean, boys were allowed to do everything they wanted. But demands were on girls. For instance, that they weren't allowed to go out, that they shouldn't do this and that, that they shouldn't go to school parties. Just a thing like that, you were not allowed to go to school parties! And my brother, he never had to do the dishes at home. These are all just small matters, but they meant so much back then. (Interview / Karlsson Minganti.)
\end{abstract}

Noor formulates her crisis as consisting of poorly fitting gender practices at home, in school, among friends, and in society in general. I would suggest that she and the other women expressed the dilemma of living under pressures from different power orders, and - from a marginalized position - having to deal with the mismatches that sometimes occur.

\section{SEXISM AND RACISM}

The women were clearly critical with certain gender issues in their families, especially the ones that they rated as unjust division of labour, and as unwanted control over their bodily behaviours, such as the dress code and movements outside the home. Control over their female chastity seemed to increase as they entered puberty, and as they came to live in a society dominated by the absence of what was perceived as Muslim moral. The young women were certainly interested in guarding their modesty; yet, when meeting with the world outside the home they were alerted about criticism against sexism, and public debates accusing Islam for being a religion that oppresses women. While they were attracted by reflections on sexism, they were confused when trying to understand the accusations against Islam. The woman whom I call Latifa phrased the dilemma like this:

In a way I can understand the Swedes. I mean, they get these images from the mass media showing Islam as something horrible. In fact, I was thinking in the same way for a while: "We Muslims are truly insane!" You know, I was so young when I came to Sweden and I got such a negative image of Islam when I watched TV. That men beat their wives. Abuse them. Islam, Islam, Islam. (Interview / Karlsson Minganti.)

Testimonies from women in their close circles about abuse in the name of Islam increased confusion. In fact, several of the women in this study lived with threats 


\section{Pia Karlsson Minganti}

about the so-called honour-related violence, that is, they experienced their families being driven by a logic which maintained that certain acts could ultimately be punished with physical violence and even death. They lived in a cultural context of honour, that is, a frame of reference where an individual's behaviour is not separated from the honour of the community. It includes the possibility of different forms of violence being perpetrated over time, by different male relatives (fathers, brothers, uncles) towards different women (mothers, sisters, aunts, and others), thus working as a general warning against trespassing (Eldén \& Westerstrand 2004). Some of the young women testified that they actually lived under threat of honour killing. Others risked less severe physical punishment, while the rest could not recall any physical reprimands at all. Common for all of them, however, was the anxiety about a possible repudiation from family and community. Quite importantly, a disconnection from one's family was generally understood as a challenge of God's will, thus a reason for transcendental punishment.

The young women's narratives of their youthful crises were also imbued with descriptions of living in a racialized order where Muslims were subordinated to non-Muslims. The woman whom I call Amal told me about explicit verbal abuse from peers at school:

When I used the headscarf I got to hear: "Okay, so you are oppressed now?!" Or:

"God, it smells like shit in here!" I got to hear such things when they passed by me. And... I thought it was horrible. (Interview / Karlsson Minganti.)

Paradoxically, and confusingly enough for the young women, the hostility towards them as Muslims often drew on the discourses that were critical to the oppression of Muslim women. Quite evidently, at least to me, they suffered from different kinds of oppression under both patriarchal and racist power orders, and they had a hard time making their own voices heard - as individuals, as women, and as members of minority groups. Tensions between these positions have been illuminated by researchers such as Floya Anthias and Nira Yuval-Davis (1992), Seyla Benhabib (2002), Nancy Fraser (2003), and Iris Marion Young (2000). Despite the differences between these theoreticians, they all emphasize the importance of deconstructing the perceptions of essential identities and cultures in order to counteract racist and androcentric values that hinder individual agency.

Nonetheless, the young women were offered a certain space for their voices, although not exactly in accordance with their own wishes. They found themselves being constantly pushed into the position of the representatives of "the Muslims" and Islam. With Islam under attack, this position often turned into a defensive stance as non-Muslims demanded elaborated statements about "what Islam says" and "what Muslims do". Researchers have pointed out how absurd it is to expect children to give an account of anything but the simplest elements in childhood faith. Yet, they are urged to propose theological explanations about social and political events in the countries that they have never visited (Jacobsen 2002, 106-109; Otterbeck 2000, 115). Amal told me about the heavy burden of being ascribed the role of a representative 


\section{Becoming a "Practising" Muslim}

for Islam and all Muslims in the world: "Sometimes I think that speaking about Islam occupies all my time, instead of just being able to manage my studies or having a good time with my friends." As I will point out later on in this article, Amal was, however, motivated to perform such an informative role, including participation in my research project, as a vital part of her religious conviction.

Yet another problem that the women associated with their teenage crises was the racialized hierarchies among Muslims. There were expressions of prejudices against other "races"/ethnicities and restrictions for the youth's friendships and marriages. There were power struggles in the congregations expressed in biased opinions about the Other. As Samira put it:

They make such a big deal of who's going to be in charge. It's a matter between different nationalities, a lot of things that I feel ashamed of. [...] Actually it's a lot of... well, differences. Muslims look down on each other. Turks are better than Arabs, and Arabs are better than Turks. And according to the Swedes they are all fools [laugh]. (Interview / Karlsson Minganti.)

To sum up, the women's narratives about their teenage crises indicate two intimately linked categories: gender and "race"/ethnicity. Eventually, "religion" was added as the third and crucial one. As their testimonies tell about those crises as a significant risk of splitting from their families and their faith, in the end these nine women did not make such a break, but chose to challenge the prevailing norms from within, that is, by enrolling in the Islamic movement.

\section{Young Muslims UNiTED}

The women describe the way out of their youth crises in terms of religious awakening.(1) Through Koran schools, siblings, or peers, they came in contact with Islamic activities targeted at adolescence. In fact, all the women within my study took part in a pioneer generation, becoming members of the very first youth associations in Sweden, attending the courses and seminars organized by them. They all belonged to the first national youth organisation founded in 1991, which at the time was called Sveriges Muslimska Ungdomsförbund (SMUF), i.e., Sweden's Muslim Youth Association. Now it is known as Sveriges Unga Muslimer (SUM), i.e., Sweden's Young Muslims. It is dominated by Sunni-Islam, but claims to welcome young Muslims regardless of their ethnicity, language, and confessional or ideological commitments. As the largest Muslim youth organisation, with an estimated 10000 members and the headquarters in Stockholm, it has reached a noteworthy position with repeated invitations to its members to participate in the mass media and other public events. It also links several local youth associations in different towns - the main arenas for the activism of the young women in my study. 


\section{Pia Karlsson Minganti}

In their associations the young Muslims were able to share their experiences of external and internal racism, as well as the confused feelings of being both ashamed and in defence of their religion. The associations also accounted for extraordinary spaces for exchanging thoughts about gender and women's rights. Time and again the young women told me about the different positive aspects of their youth groups, not least strong friendship. Amal:

\section{I think that our course has given me so much. I've got friends. I had friends also before, Swedes and non-practising Muslims and so on. But the friends I have here, they are totally wonderful! They are the kind of friends that I would never have dreamt about having. (Interview / Karlsson Minganti.)}

She made a gathering movement with her hand and pulled a clenched fist to her chest. I interpreted her gesture as an illustration of the unity among the youth. Also, Latifa's body was moving enthusiastically when she described amity in her local association. "You must come and see for yourself!" The invitation was followed by a performance showing me how the girls run to greet and hug each other, and how the young ones call themselves "sisters and brothers in Islam". I deem her performance as expressing an important motive for the youth's engagement in the Islamic movement, namely the desire for identification and alliance. According to the cultural theorist Lawrence Grossberg, it is not necessarily a rational and initiated consideration that guides the youth, but feelings of attraction or repulsion, likes and dislikes (Grossberg 1997, 13-14). The women's Islamic engagement coincided with their emerging selfdefinitions in wider societal contexts, and the questioning of their parents' norms. Just like for any other teenager this process was impregnated by distinctions between I/Us and the Other(s). What makes me alike? What makes me different? Who am I and who will I become? Thus, in a situation which for the teenage women mostly appeared as "chaotic" (see Noor's quotation above), I would, from a researcher's perspective, say that they were not only motivated by the Islamic doctrine, but also by finding a sufficient platform for identity construction. From this perspective, the young Muslims' achievement of religious ideology and community could be understood in terms of emotional investments and alliances that Grossberg labels affective empowerment (Grossberg 1997, 31-32, 76).

Even if the women sometimes associated life in Sweden with vulgarity, callousness and alienation, the Islamic community evoked other kinds of emotions. For Latifa, the sight of a young woman in hijab riding a motorbike was uplifting, as was the woman's positive response with a quick smile and a waving hand. Latifa also expressed a feeling of being personally addressed by a charismatic religious leader on a videotape, at the same time being aware of sharing this feeling with a large number of consumers of this very videotape all over the world. Similarly, Samira could watch white-dressed pilgrims on TV embodying a global Muslim community (umma), regardless of national or social background. When Amal went down on her knees to pray, she experienced herself being connected with suffering relatives in 


\section{Becoming a "Practising" Muslim}

her former home country. Noor testified about similar emotions of solidarity when confronted with images of Muslim children in despair. Rania quite simply fell in love with a "practising" Muslim boy and embraced his religious conviction: "He is so wonderful. We have such a wonderful religion."

\section{Pious Practices}

The women explained the way out of their youth crises in terms of a religious awakening or "return to Islam", and this, according to my interpretation, involves not only the dimensions of affective empowerment and cultural contestation described above, but certainly also a dimension of religious conviction. When "returning to Islam", they joined Muslims worldwide, following the call of the Islamic revival movement "Back to Islam!" With the Islamic revival I refer "not only to the activities of stateoriented political groups but more broadly to a religious ethos or sensibility that has developed within contemporary Muslim societies" (Mahmood 2005, 3). It has swept over the world since at least the 1970s, and has left its imprints on individuals and socio-cultural landscapes with an increased number of mosques and attendance by both men and women, the construction of "Islamic" schools, hospitals, and social services, the increased production and consumption of religious media and literature, intellectuals who comment on the world from a religious perspective, everyday codes of dressing and behaviour (Mahmood 2005, 3-4).

The revival movement's call for a "return to Islam" entails two aspects. Firstly, Muslims are urged to turn to Islam as the main guide for the individual and society, which refrains from other interests and ideologies, including the unrestrained "Westernization". Secondly, Muslims ought to turn back to the "authentic" sources - the Koran and Sunna - to find the "true" message of Islam, free from human habits and delusions, especially the misinterpretations made by religious, political, and economic elites supposedly corrupted by "traditions" and worldly interests. In the young women's everyday life, this call was expressed in their comprehensive practising of Islam, and their ensuring that these practices were performed in accordance with the "true" Islam. They applied the distinction between "religion" and "cultural traditions" and perceived themselves to be detecting the "authentic" message of Islam and discarding "cultural misunderstandings". As one possible strategy, their dismissal of "false" hadiths (narrations about the exemplary sayings and conducts of Prophet Muhammed), could be mentioned, along with the highlighting of such hadiths that bring to the fore women's interests.

The young women's piety included their ambition to understand the motives of their religious practices. In fact, within the framework of Islamic revival they received recognition as pious subjects, personally responsible before God. This means that also women were ascribed the right and duty to look for religious knowledge and support for strengthening their piety. In turn, this means that the young women found some space for themselves in the mosque and in other knowledge-producing 


\section{Pia Karlsson Minganti}

arenas - spaces that are not always assured for women, neither in Sweden, nor in Muslim societies.

\section{ISLAMIC IDENTITY}

Indeed, "practising Muslim" was the emic definition that the young women provided for their new devout position - a Muslim that continually practises Islam, with a reflexive understanding of the pious meanings, forms, and motives of these practices. Following this, the women's self-identity was constructed in contrast to the category of the "non-practising Muslim" who, instead, embodies the tacit, unreflected knowledge of Islam as characterized by the first dimension of the women's key scenario - a Muslim with a naive relation to the religion into which he or she was "born" - or by the second dimension: a Muslim in crisis, led astray from the "straight path of Islam".

Another intimately linked dichotomy was the one of an "Islamic" versus a "Muslim" dimension. The former would be characterized by the seriousness of the awakened, "practising" Muslim. The latter would be associated with the "cultural" or "ethnic" aspect, aiming at particular ethnic customs in the women's former homecountries. As phrased by Amal: "In my home-country women wear their headscarves with the hair sticking out. It's their tradition and not in accordance with Islam." Secondly, the cultural/ethnic aspect of "Muslimness" would aim at what the French researcher on Islam Olivier Roy refers to as a Muslim neo-ethnicity (Roy 2004, 124-137). By this he means the construction of a universal Muslim identity, intimately linked to the common position of "the Muslim" ascribed to them by non-Muslims. By the prefix "neo" Roy suggests that earlier particular ethnic or national categories are no longer relevant, but only the common reference to Islam, and by "ethnicity" - that religion, however, is not primarily understood in terms of faith, but as an inherited set of cultural patterns (Roy 2004, 124).

The women's usage of a Muslim neo-ethnicity could be traced in the following quotation from Amal: "There are women today who wear bijab to show that they are Muslims. But they do not pray and do not behave according to Islam. So, their wearing the hijab is not worth anything before God." And Leila: "For instance, if I wear a headscarf in order to have everyone thinking 'Wow, you are cool!', then it does not count, so to speak. No, you really need the intention to wear it because it is prescribed in the Koran and because God wants you to." Indeed, exhibitions of bijab as a mere ethnic marker, or visits to the mosque only during festivities such as Ramadan, were perceived by the awakened "practising" women as "un-Islamic" and in line with what the American anthropologist Saba Mahmood captures as a "folklorization of worship" (Mahmood 2005, 48-53). In her study among pious women activists in Egypt, Mahmood highlights the women's critique of the fact that: 


\section{Becoming a "Practising" Muslim}

the ritual acts of worship in the popular imagination have increasingly acquired the status of customs or conventions, a kind of "Muslim folklore" undertaken as a form of entertainment or as a means to display a religio-cultural identity. According to them, this has led to the decline of an alternative understanding of worship, one in which rituals are performed as a means to the training and realization of piety in the entirety of one's life. (Mahmood 2005, 48.)

The religious venture of the young women within my study aimed, among other things, at restoring this understanding of worship - as practising Muslims with an Islamic point of reference.

\section{Pious Subjects of the New Generation Muslims}

To conclude this article, I would like to discuss some empowering aspects that the women perceived by becoming "practising Muslims" of the "true" Islam. I begin by commenting on their dilemmas in connection to racialized power orders. When enrolling in Muslim youth associations, influenced by the Islamic revival, the young women were offered consolation by the notion of Islam as a religion that counteracts racism, both such racism that is ascribed by "outsiders" and the one operating "inside" Muslim communities.

\section{Latifa: Islam gets rid of all that racism, skin colour, or that cultural stuff. All are equal before God. \\ Pia: Aha. And that feels good? \\ Latifa: Indeed it does! Every time I look at my friends I feel so bappy. It's us, the coming generation, we, the Muslim youth in Sweden, raised in Sweden, sort of... We are the ones who are going to eliminate racist thinking, because we do not care about where people come from. We do not think like that. (Interview / Karlsson Minganti.)}

Latifa and the other young women adopted the idea about Islam as an anti-racist religion, and perceived themselves fitted to embody this progress as "the new generation" Muslims. As such they were supposedly less biased and more enlightened than the parental generation, thanks to their increased knowledge about the "true" Islam and its message about unification in piety.

As to external racism, the women expressed feelings of alienation from non-Muslim Swedes, who constantly and forcedly positioned them as the Other, while demanding answers about "what Islam says" and "what Muslims do". The women's Islamic community, nonetheless, offered them a positive understanding of this representational burden. They were enlightened about the concept of dawa, that is, a religious duty to inform about Islam, which would reward them with dignity and 


\section{Pia Karlsson Minganti}

religious merits. Furthermore, the women fostered a notion about dawa as a possible means for preventing non-Muslims' racializing practices. If only people could get information about the "true" Islam and disregard "cultural misconceptions", Muslims would gain respect and recognition. This perception is illustrated in the (emphasized) lines added to Latifa's above quotation:

In a way, I can understand the Swedes. I mean, they get these images from the mass media showing Islam as something horrible. In fact, I was thinking in the same way for a while: "We Muslims are truly insane!" You know, I was so young when I came to Sweden and I got such a negative image of Islam when I watched TV. That men beat their wives. Abuse them. Islam, Islam, Islam. But this is, in fact, a matter of the so-called Muslims doing stupid things, and then the Swedes cannot understand that this is actually not Islam. But I think that the only thing one has to do is to change this negative image. (Interview / Karlsson Minganti.)

Latifa hopes to "inform away" racism. The task of providing information is understood in terms of dawa, and based on the distinction between "true religion" and "cultural misconceptions", "real" and the "so-called" Muslims. As indicated in the quotation, this distinction has extraordinary implications also for gender relations and women's rights. In line with Latifa's rejection of physical abuse, all women in my study firmly stated that "honour killings" and "genital mutilation" are inconsistent with Islam. And out of the same rationale they took part in deciding about the ways in which Islam should be applied in their everyday life - here and now. Indeed, it would be appropriate for them to work outside the home, study at university, and drive a car. The young women all admit to adhering to several religious leaders simultaneously (including those found on the Internet and on video- and audio-tapes) and then to taking independent decisions on whose teachings to rely on. This is, undeniably, a break with the tradition to hold on to one single Islamic law school given to any individual Muslim by birth into a certain family and nationality. And this, again, is a sign of religious revival: the sidestepping of traditional authorities (religious, parental) and the participation of "laymen", women and the youth in the reading of the sacred scriptures.

Hence, I claim that the young women were recognized as religious subjects, allowed to enter mosques and to participate in pious activism and learning. They were reflecting on their religion and questioning their parents, but did not break with these crucial points of reference. While their parents could still be proud over their daughters growing up and maturing as Muslims, their religious transformation could also be read as a way of making independent selves, with an alternative "Islamic" community outside families and ethnic networks. This reading coincides with the young women's narratives, and makes up a basic argument in their counteracting the stereotypical description of "the Muslim woman" as a passive victim to multiple oppressions. Thus, I would suggest that the recognition of the women as religious subjects could lead to a general recognition of them as capable persons with voices 


\section{Becoming a "Practising" Muslim}

of their own. And this in turn allows for an understanding of the Islamic revival and Muslim youth associations as a way out of sexist and racist oppression.

This kind of "success story" is an important one to be told. I would, however, like to alert the reader of a parallel story of the women's enrolment in the Islamic movement as a way into the reproduction of male dominance, honour ethics, exclusion, and hindrance for women's agency. The complexity of the Islamic revival could find its way here only partially, owing to the delimited scope of this article, but is a crucial point in my overall analysis of the young women's everyday negotiations on gender and agency (Karlsson Minganti 2007).

\section{ACKNOWLEDGEMENTS}

This article draws on the research for the author's PhD in Ethnology at Stockholm University, funded by the Swedish Council for Working Life and Social Research and the Bank of Sweden Tercentenary Foundation.

\section{Notes}

1. I understand the women's religious awakening in terms of a revival or conversion. Actually, I asked the women if they would use the term reversion to describe their religious transformation, that is, the returning to the faith that they were already in, only now in a more elaborated way. I was associating with the Islamic revival movement's call for "returning to Islam" (see below) and to some young "practising" Muslims in England, who would define themselves as reverts (Karlsson 1999; see also Jacobsen 2002: 256). The young women denied using the term, but stated that those people normally referred to as converts to Islam sometimes would. In doing so, they would adopt a wide definition of being a Muslim, namely: 1) all human beings are born Muslims; 2) they are later led astray from "the straight path of Islam" (something which children to non-Muslim parents would be specifically vulnerable to, cf. this article's section "Born a Muslim"); 3) some ones are finally returning on track - as reverts. For the women in my study, it seemed satisfactory enough to talk about themselves as having become "practising" Muslims. Any distinction from "non-Muslim" converts/reverts to Islam would be based on the will to mark out differences in experience rather than detach from the category of people as such. Converts/reverts were, in fact, highly appreciated members of the young women's Muslim youth associations, and whenever someone chose to "embrace Islam", they would be celebrated with a party or some sort of ceremonial welcoming. 


\section{Pia Karlsson Minganti}

\section{REFERENCES}

\section{Interviews and Observations:}

Interviews and observations done by the author, PhD Pia Karlsson Minganti, between 1998 and 2002. The interviews are recorded, transcribed, and in this article, translated from Swedish into English. Recordings, transcriptions and field notes are stored by the author, as a part of the ongoing research.

\section{Literature}

ANTHIAS, FLOYA 2002: Where Do I Belong? Narrating Identity and Transnational Positionality. - Ethnicities 2(4).

ANTHIAS, FLOYA \& YUVAL-DAVIS, NIRA 1992: Racialized Boundaries. Race, Nation, Gender, Colour and Class and the Antiracist Struggle. London: Routledge.

BENHABIB, SEYLA 2002: The Claims of Culture. Equality and Diversity in the Global Era. Princeton: Princeton University Press.

BERGER, PETER L. \& LUCKMANN, THOMAS 1991: The Social Construction of Reality. A Treatise in the Sociology of Knowledge. London: Penguin Books. [1966]

BOURDIEU, PIERRE 1977: Outline of a Theory of Practice. Cambridge: Cambridge University Press.

CLIFFORD, JAMES \& MARCUS, GEORGE E. (eds.) 1986: Writing Culture. The Poetics and Politics of Ethnography. Berkeley: University of California Press.

DE LOS REYES, PAULINA \& GRÖNDAHL, SATU (eds.) 2007: Framtidens feminismer. Intersektionella interventioner $i$ den feministiska debatten. Hägersten: Tankekraft.

ELDÉN, ÅSA \& WESTERSTRAND, JENNY 2004: Hederns försvarare. Den rättsliga hanteringen av ett hedersmord. - Kvinnovetenskaplig tidskrift 25(3).

FRASER, NANCY 2003: Den radikala fantasin. Mellan omfördelning och erkännande. Göteborg: Daidalos.

GROSSBERG, LAWRENCE 1997: Dancing in Spite of Myself. Essays on Popular Culture. Durham, (NC): Duke University Press.

HARAWAY, DONNA 1991: Simians, Cyborgs, and Women. The Reinvention of Nature. London: Free Association Books.

JACOBSEN, CHRISTINE M. 2002: Tilhorighetens mange former. Unge muslimer $i$ Norge. Oslo: Unipax.

KARLSSON MINGANTI, PIA 2007: Muslima. Islamisk väckelse och unga kvinnors förhandlingar om genus i det samtida Sverige. Stockholm: Carlsson bokförlag.

- 2004: Mosques in Sweden. On Identity and Spatial Belonging. - Siikala, AnnaLeena, Klein, Barbro \& Mathisen, Stein R. (eds), Creating Diversities. Folklore, Religion and the Politics of Heritage. Helsinki: Finnish Literature Society.

KARLSSON, PIA \& SVANBERG, INGVAR (eds) 1997: Religionsfribet $i$ Sverige. Om möjligheten att leva som troende. Lund: Studentlitteratur. 


\section{Becoming a "Practising" Muslim}

- 1995: Moskéer i Sverige. En religionsetnologisk studie av intolerans och administrativ vanmaket. Uppsala: Svenska kyrkans forskningsråd.

KHAN, SHAHNAZ 2002: Aversion and Desire. Negotiating Muslim Female Identity in Diaspora. Toronto: Women's Press.

MAHMOOD, SABA 2005: Politics of Piety. The Islamic Revival and the Feminist Subject. Princeton: Princeton University Press.

MASCIA-LEES, FRANCES E. \& JOHNSON BLACK, NANCY 2000: Gender and Anthropology. Prospect Heights (IL): Waveland Press.

MOHANTY, CHANDRA TALPADE 2003: Feminism Without Borders: Decolonizing Theory, Practising Solidarity. Durham (NC): Duke University Press.

OKIN, SUSAN MOLLER 1999: Is Multiculturalism Bad For Women? Princeton: Princeton University Press.

ORTNER, SHERRY 1973: On Key Symbols. - American Anthropologist 75(5).

OTTERBECK, JONAS 2000: Islam på svenska. Tidskriften Salaam och islams globalisering. Almqvist \& Wiksell International.

ROY, OLIVIER 2004: Globalised Islam. The Search for a New Ummah. London: Hurst \& Company.

SAID, EDWARD 1978: Orientalism. London: Routledge \& Kegan Paul.

THURÉN, BRITT-MARIE 1998: Att erövra barerna. Former och platser för kulturell förhandling kring genus i Spanien. - Kvinnovetenskaplig tidskrift 19(3-4).

YOUNG, IRIS MARION 2000: Inclusion and Democracy. Oxford: Oxford University Press.

Doctor Pia Karlsson Minganti is a Stockholm-based researcher specialised on Islam and Muslims in Sweden. 